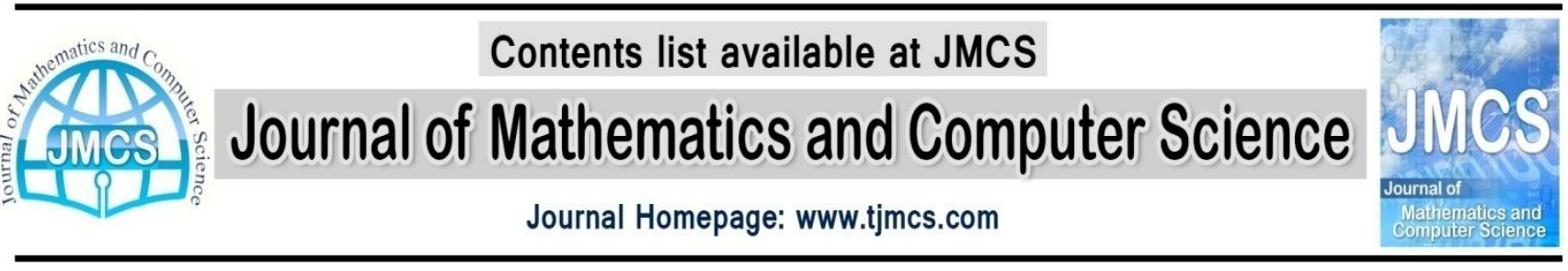

\title{
Mathematical modeling of PEM Fuel Cell power module and Ultra-Capacitor for Vehicular Power System
}

\author{
Mehdi Soltani ${ }^{1}$, Akram Dadkhah $^{2}$ \\ Department of electrical engineering, Islamic Azad University, Tiran Branch, Tiran, Iran ${ }^{1,2}$ \\ E-mail:meh_soltani@yahoo.com,A_dadkhahchem@yahoo.com
}

Article history:

Received December 2013

Accepted January 2014

Available online February 2014

\begin{abstract}
Fuel cells (FC) are widely recognized as one of the most promising technologies to meet future power requirements of vehicular applications. However, a FC system combined with some energy storage systems (ESS) can perform better for vehicle propulsion as considering several points. As the additional ESS can fulfill the transient power demand fluctuations, the FC system can be downsized to fit the base power demand without facing peak loads. Because batteries have low power densities and limited lifetimes in highly cyclic applications, ultra capacitors may be the ESS medium of choice. Ultra-capacitor (UC) bank, on the other hand, can supply a large burst of power but cannot store much energy.

The goal of this study is to combine an experimental validated fuel cell model which is capable of characterizing fuel cell steady state performance as well as dynamic behavior with an ultra-capacitor bank model. The experimental results have been obtained from a Nexa ${ }^{\mathrm{TM}}$ PEM fuel cell power module under different load conditions. Based on this model, a simulator software package has been developed using the MATLAB® and Simulink® software and Simulation results have been carried out.
\end{abstract}

Keywords: curve fitting technique, dynamic model, equivalent internal resistance, isothermal condition, UC model.

\section{Introduction}

FUEL CELL (FC) power plants are electrochemical devices that convert the chemical energy of a reaction directly into the electrical energy and expected to play an important role in the power generation field by virtue of their inherently clean, efficient and reliable service. Their use is spreading widely and promising applications include portable power, transportation, residential power and distributed power for utilities. Among the various types of fuel cells, the proton exchange membrane (PEM) fuel cell is providing reliable power at steady-states; however, it is not able to respond promptly to a load step change due to the delay time for the fuel flow rate to adjust. By operating the FC and UC in parallel, both steady-state and peak power demands can be satisfied. Without the ultracapacitor (UC) bank, the FC system would have to supply all power demand, thus increasing the size and cost. The UC also is used to provide the difference between the load demand and the output power 
generated by the FC. UCs are electrical energy storage devices, which offer significantly better energy densities than conventional capacitors, better power densities than conventional batteries, and can be constructed in modular and/or stackable format. The charge and discharge times of a UC varies from fractions of a second to several minutes, while providing maintenance-free operation. UCs provide lowest cost per Farad, extremely high cycling capability, and are environmentally safe [2], [3]. Because of the aforementioned unique characteristics, UCs are utilized for a wide range of applications, especially during the transient power demand fluctuations.

Since the fuel cell is an electrochemical energy conversion device that converts fuel into electricity, its dynamic behavior depends both on chemical and thermodynamic processes. To understand and analyze fuel cell stack performance at the design stage, computer model of fuel cell stack is needed [1].

To ensure a system level simulation, fuel cell stack model should be able to reflect fuel cell characteristics accurately. Two common approaches of fuel cell modeling are: steady-state model and dynamic model. Steady state model reflects the V - I relationship of the fuel cell and can be divided into two categories: analytical model and empirical model. Empirical model is derived from experimental results which are applied to predict the effect of different input parameters on the voltage-current characteristics of the fuel cell, without examining in depth the physical and electrochemical phenomena involved in fuel cell operation. Amphlett et al. [8] presented such a " "phenomenological" model with a good mechanistic background, which was later further developed [9], also catering for ageing effects. Since the model parameters are obtained from data fitting technique, the empirical model is accurate only in a small operating range. However, when all fuel cell variables for analytical model are unavailable; simplicity is the most attractive feature of the empirical model.

Dynamic model, on the other hand, is able to reflect the transient performance of the fuel cell during the load insertion and extraction. Regarding the fuel cell dynamic performance, several dynamic effects are included in a fuel cell system. These have time constants varying over a wide range of order of magnitude. The thermal time constant of the fuel cell has the highest order of the magnitude (about $102 \mathrm{~s}$ ). Most previous studies only take this dynamic effect into consideration while neglect the others. However; when large load change occurs over a small period of time, "charge double layer" phenomenon of the fuel cell cannot be neglected. The thermal dynamics has little effect on the cell performance in such conditions as the stack temperature does not vary much [2]. In such a situation, the dynamics of the internal resistance characteristics of fuel cells have to be considered. In fact, both the stack temperature and internal resistance will have effects on the static and dynamic characteristics of the fuel cell output. Although such effects may not be so significant in the case of large scale fuel cells; however, for smaller fuel cells in the range of a few $\mathrm{kW}$ levels, such as the Nexa ${ }^{\mathrm{TM}}$ PEM fuel cell power module, it has been observed that both the stack temperature and the equivalent internal resistance of the power module can change dramatically with different load conditions. The objectives of this paper are to develop an empirical model for Nexa power module suitable for steady stated and dynamic modeling and to investigate the effects of temperature and equivalent internal resistance on the output characteristics of a PEM FC power module. This investigation is based on the work reported in [13] with considering the effects of temperature and current level on the effective internal resistance. A $1.2 \mathrm{~kW}$ PEMFC system can essentially satisfy the base power required for a small hybrid electric vehicle (HEV). However, the required power varies significantly during different driving cycles and in transient fluctuation. To overcome the above mentioned limitations, we use a combined FC and UC system, where the FC systems supplies the basic load (up to $1.2 \mathrm{~kW}$ ) and the UC bank supplies the additional power required during the peak power demand and load switching. Simulation results obtained using MATLAB $®$, Simulink®, and SimPowerSystems ${ }^{\circledR}$ are presented to verify the effectiveness of the proposed technique. 


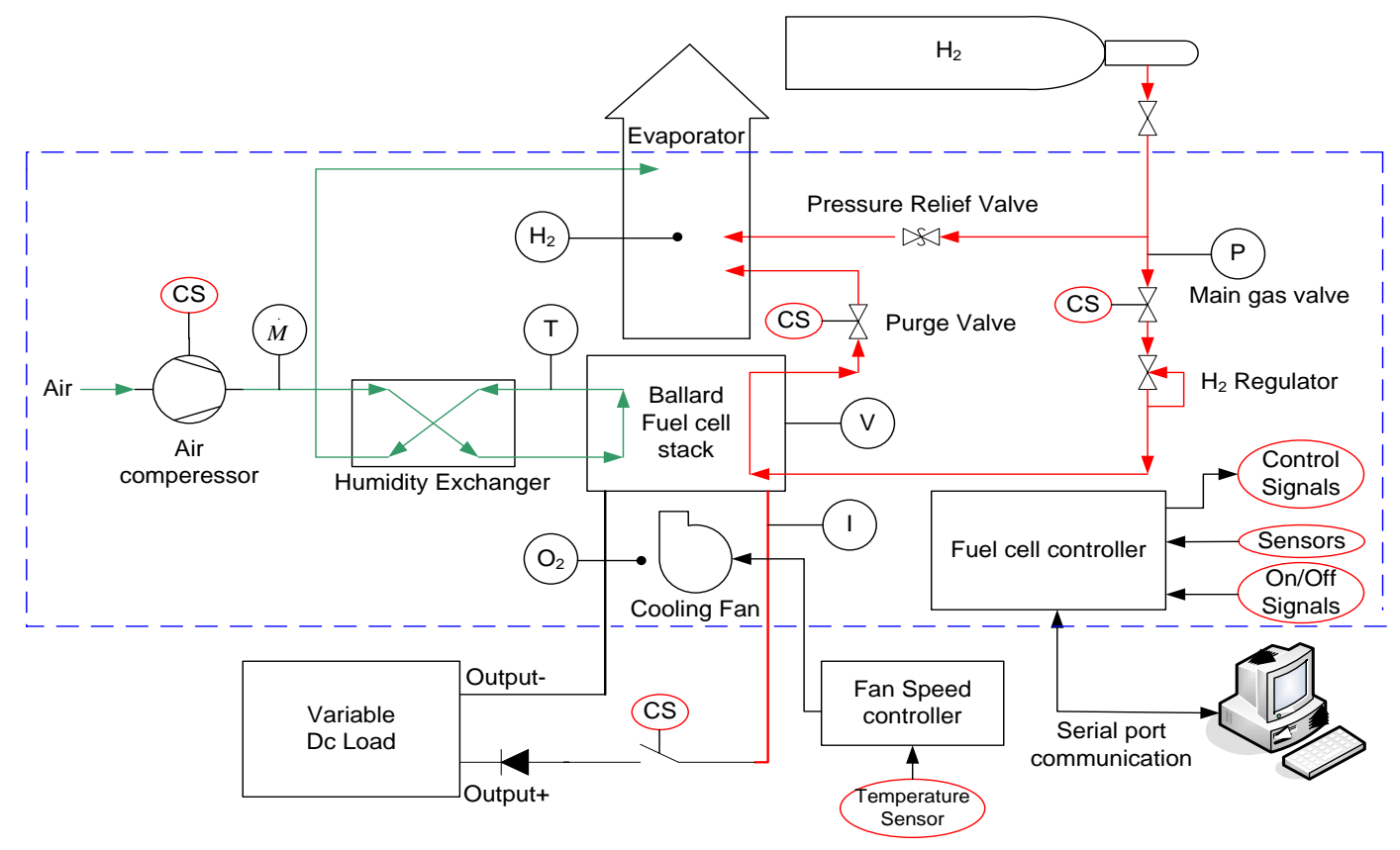

Figure.1. Schematic diagram of the experimental setup

\section{Test Equipment}

The experimental data presented in this paper was obtained from a $1.2 \mathrm{~kW}$ Ballard PEM fuel cell (Nexa ${ }^{\mathrm{TM}}$ Power Module, SN1568), which is currently being used by our research group. The Nexa ${ }^{\mathrm{TM}}$ power module is an automated PEMFC system, providing unregulated dc power form a supply of hydrogen and air. Its operation is limited only by the fuel purity requiring no more than $0.01 \%$ of total inert gases at a rated power of $1200 \mathrm{~W}$. It contains a BALLARD® fuel cell stack, as well as all the ancillary equipment necessary for fuel cell operation. Ancillary subsystems include hydrogen delivery, oxidant air supply and cooling air fan. Onboard sensors monitor system performance and the control board fully automates operation. The onboard sensors have been used for measurement in our experimental tests. The accuracies of the sensors are presented in table.1.

\begin{tabular}{cc}
\multicolumn{2}{c}{ Table.1. the accuracy of the on board sensors } \\
\hline Current sensor & $+/-2 \%$ \\
\hline H2 Sensor & $+/-1 \%$ \\
\hline O2 Sensor & $+/-4 \%$ \\
\hline Air Mass Flow sensor & $+/-4 \%$ \\
\hline Voltage sensor & $+/-4 \%$ \\
\hline Ambient temperature sensor & $+/-1.25^{\circ} \mathrm{C}$ \\
\hline Temperature sensor (stack) & $+/-2 \%$ \\
\hline
\end{tabular}

The Nexa ${ }^{\mathrm{TM}}$ system also incorporates operational safety systems for indoor operation. Fig.1 illustrates the schematic diagram of the experimental setup. The diagram also shows the Nexa ${ }^{\mathrm{TM}}$ system boundary and important interface connections to the DC module. Hydrogen, oxidant air, and cooling air must be supplied to the unit, as shown in fig.1. Exhaust air, product water and coolant exhaust is emitted. The designed operating temperature in the stack is around $65^{\circ} \mathrm{C}$ at full load [14]. The stack is composed of 47 cells, each with a $110 \mathrm{~cm} 2$ membrane [15]. The operating pressure at the fuel supply inlet was chosen to be $138-276 \mathrm{kPa}$. The fuel supply pressure to the stack was $34.5 \mathrm{kPa}$, and the pressure of air oxidant was defined as $15 \mathrm{kPa}$. The system is auto humidified and air-cooled by a small fan. Concerning the hydrogen feeding of the fuel cell, a dead-end mode with flushes was adopted. Also, a PC was used for the acquisition of the measured values which have been recorded by 
NexaMon software from Ballard and, in order to simulate a variable power demand, the energy produced was delivered to a DC load. Since after start-up, the power module will provide all the necessary internal power requirements for operation, such as cooling fan, air compressor, and the control circuit board, the output characteristics of the power module can be somewhat different from that of the fuel cell stack itself. Since the power module will be used as a unit and be integrated into a hybrid vehicular power system, it is necessary to have a complete knowledge of the dynamic characteristics of the entire power module, rather than just that of the fuel cell stack.

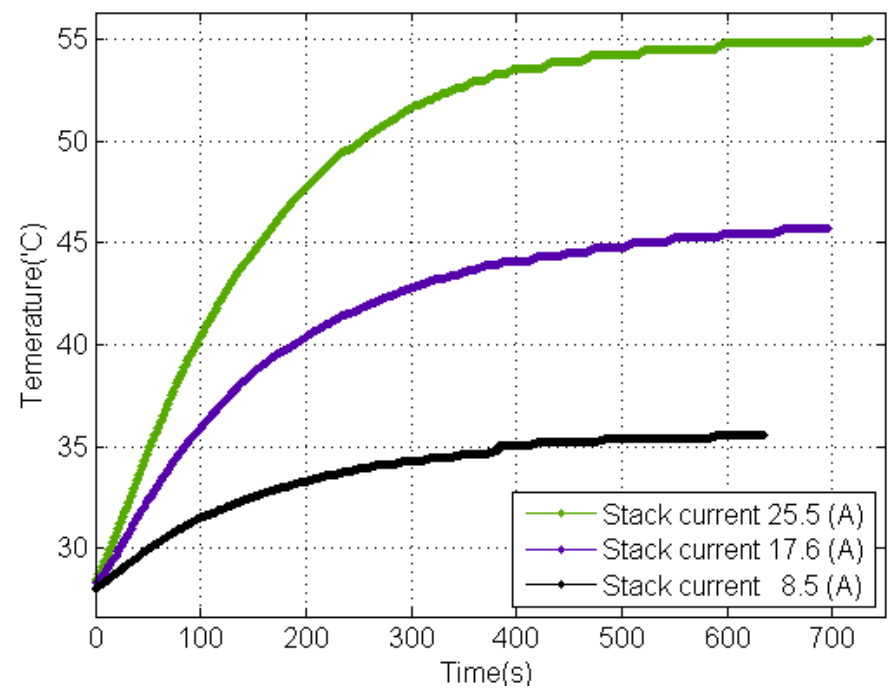

\section{Fig.2. Temperature profile as a function of module current \\ 3.Experimental investigation of temperature, internal resistance, and no load voltage}

To study the effects of variation of temperature on the output characteristics of the power module, such as internal resistance and no load voltage, some experimental tests have been applied. Therefore a controller as shown in fig. 1 has been used for adjusting the speed of cooling fan according to the required temperature in the experiment so that the isothermal situation has been maintained.

\subsection{Stack temperature characteristics}

To investigate the variation of temperatures for different load conditions, the hydrogen pressure is kept at $34.5 \mathrm{kPa}$. The load connected to the power module is adjusted by varying load resistances. The engaged procedure of the experiment has been described hereafter. At the First step, a load with 8.5A current is drawn from the fuel cell and the variation of stack temperature from the room temperature $\left(27.5^{\circ} \mathrm{C}\right)$ up to the maximum $\left(36^{\circ} \mathrm{C}\right)$ is logged in about $10 \mathrm{~min}$. In these experiments, the main controller of fuel cell controls the fan speed and our controller is switched off. The second step of the experiment has been established after cooling the stack to the ambient temperature. At the second step, the temperature reaches to $47^{\circ} \mathrm{C}$ in about $11 \mathrm{~min}$ if the load current is increased to 17.6A. If the output current is further increased to $25.5 \mathrm{~A}$, the temperature will reach to $55^{\circ} \mathrm{C}$ in about $12 \mathrm{~min}$ from ambient temperature. Subsequently, as the current changes, the temperature of the fuel cell stack including the final temperature and the time constant of variation changes, and the rate of changes is proportional to the level of the load. The results of these tests are shown in fig.2 It should be noted that there are some variations of the cell temperature along the stack from the inlet to the outlet as discussed in the literature; however, the Nexa ${ }^{\mathrm{TM}}$ fuel cell stack is air-cooled, the cooling fan draws air from the ambient not from the oxidant stream so as to cool the fuel cell stack uniformly [15]. Therefore, those variations can be neglected, and the measured temperature is an average value. 


\subsection{System internal resistance}

As mentioned in Section 2, after start-up, the Nexa ${ }^{\mathrm{TM}}$ power module will provide all the necessary internal power which is required to sustain the operation, such as cooling fan, air compressor, and the control circuit board. These devices cannot be separated from the module, therefore, they should be considered as an integral part of the module. As a result, the equivalent internal resistance Rint of the module is different from the internal resistance of fuel cell stack which is often considered in the literature, even though it may be true that the big part of Rint is due to the internal resistance of the stack. When the power module is used as an energy source, it is more accurate to use Rint to measure the internal resistance. To investigate the characteristics of this equivalent internal resistance, Rint, a resistive load bank RL is used, and the above mentioned fan speed controller is employed to maintain an isothermal stack temperature. In these experiments at first a warm up procedure has been applied to increase the stack temperature to the level in which the test is done. The load is adjusted to obtain different output currents from the module. By considering Ifc as the module output current and VL as the output voltage of the power module when a load is connected, Rint can be calculated by

$$
R_{\text {int }}=\frac{\left(V_{0}-V_{L}\right)}{I_{f c}}
$$

V0 is no load voltage of the stack which here supposed to $43.25 \mathrm{~V}$.

The output characteristics of the Nexa ${ }^{\mathrm{TM}}$ power module from no load to full load at different stack temperatures have been examined. The relationship between the equivalent internal resistance, Rint, and the module output current has been recorded and illustrated in fig.3. When a fuel cell is connected to a load, the output voltage is always less than the open-circuit voltage, because there are some voltage drops across the fuel cell caused by the activation losses, ohmic resistance voltage drops, and concentration over potential [11]. Therefore, there are equivalent activation resistance, equivalent ohmic resistance, and equivalent concentration resistance correspondingly. The total internal resistance of fuel cell stack consists of these resistances, which are current- dependent and temperature-dependent, and it mainly determines the equivalent internal resistance of the power module.

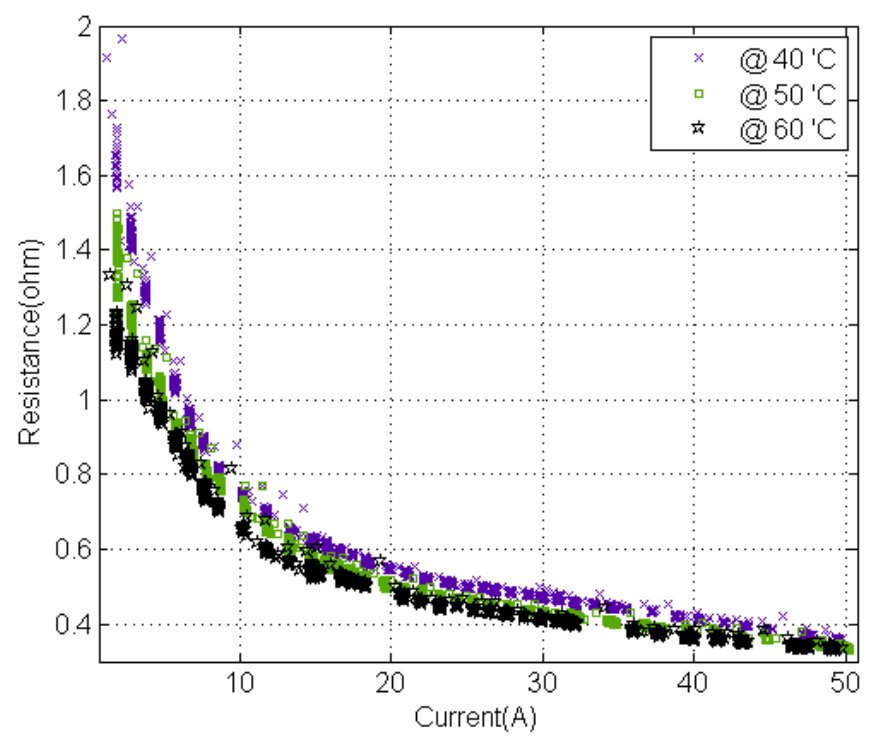

Fig.3. The relationship between Rint and system current for different temperature

Fig.3 clearly shows that when the stack current increases, the equivalent internal resistance dramatically decreases. The results of the experiments have indicated that both the stack temperature 
and the equivalent internal resistance will change with the variation of load currents. However the thermal dynamics has little effect on the cell performance in short time because it has a big time constant. Consequently, the assumption of a constant stack temperature and internal resistance would not be adequate in the case of a Nexa ${ }^{\mathrm{TM}}$ PEM power module. Such changes have to be taken into consideration when constructing a dynamic model.

\subsection{No load voltage variation}

In this section a new method for estimation of no load voltage has been presented. Three different experiments have been evaluated on the no load voltage of stack when the stack temperature decreases to the ambient temperature. At the first experiment the stack temperature decreases to the ambient temperature $\left(28{ }^{\circ} \mathrm{C}\right)$ from $35.57{ }^{\circ} \mathrm{C}$ in about $9 \mathrm{~min}$. At the second experiment the stack temperature diminishes to the ambient temperature from $45.72{ }^{\circ} \mathrm{C}$ in about $12 \mathrm{~min}$. Finally the stack temperature lessens to the ambient temperature from $55{ }^{\circ} \mathrm{C}$ in about $22 \mathrm{~min}$. Fig. 4 clearly shows that when the stack temperature decreases, the no load voltage decreases. Although the final temperature of three diagrams in fig. 4 is equal to $28^{\circ} \mathrm{C}$, the no load voltages are not the same. This difference is because of the different humidity level of the three conducted experiments. The third experiment was obtained when the humidity level is poor (immediately after start up) while the others are in high level humidity. Because of the fact that fuel cells work at an acceptable degree of humidity, the difference which is about 0.5 volt has been considered by adding a constant value as offset to the predicted voltage at poor humidity condition.

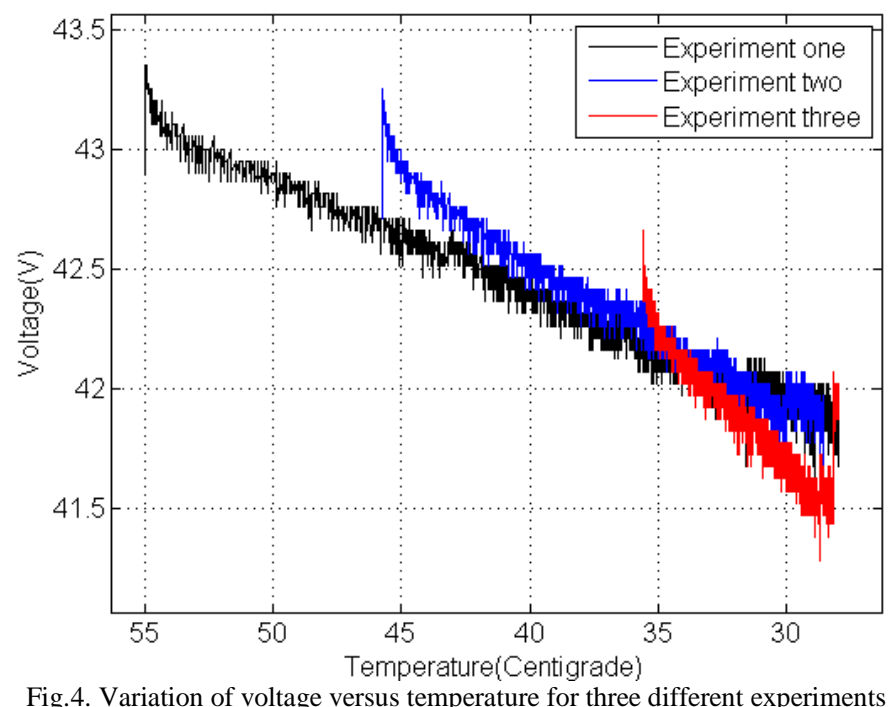

\section{Dynamic model description}

\subsection{Dynamic of temperature}

Using curve fitting toolbox of MATLAB ${ }^{\circledR}$ and Simulink ${ }^{\circledR}$ software with the experimental data presented in fig.2, the dynamic characteristics of the temperature can be approximated by (2), (3), and (4). Curve Fitting Toolbox ${ }^{\mathrm{TM}}$ provides graphical user interfaces (GUIs) and command-line functions for fitting curves and surfaces to data. The toolbox also supports nonparametric modeling techniques, such as interpolation and smoothing [16]. 


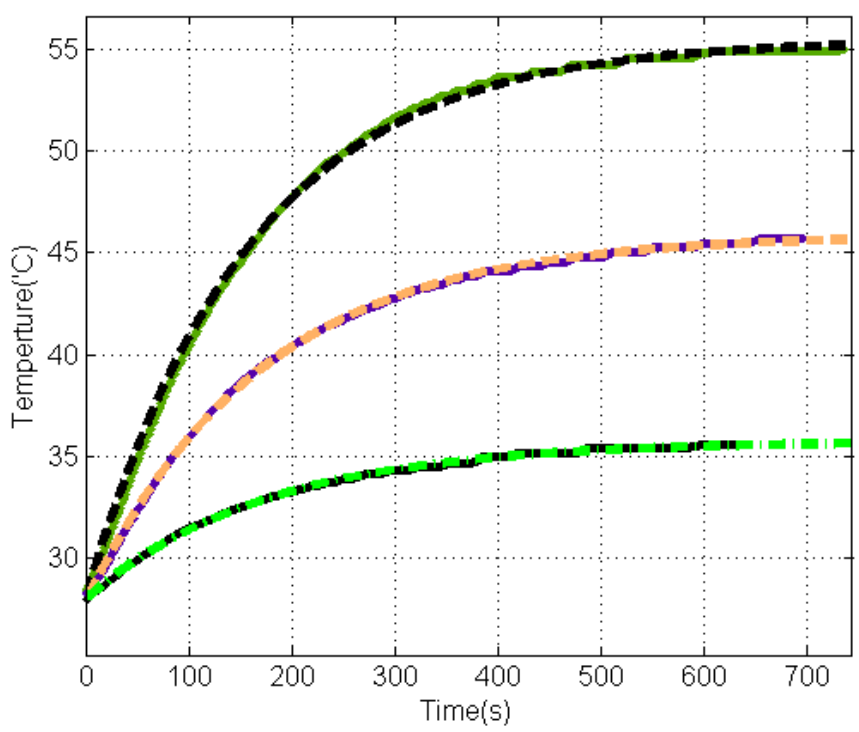

Fig.5. Comparison between the measured and computed stack temperatures.

$$
T(t)=T_{0}+\left(T_{\text {final }}-T_{0}\right)\left(1-e^{-t / \tau}\right)
$$

where the time constant can be expressed as:

$$
\tau=p_{1} \times I_{f c}^{2}+p_{2} \times I_{f c}+p_{3}
$$

and $\mathrm{T}_{\text {final }}$ is the final temperature of the fuel cell stack $\left({ }^{\circ} \mathrm{C}\right)$ which can be expressed as:

$$
T_{\text {final }}=p_{4} I_{f c}+p_{5}
$$

here $\mathrm{I}_{\mathrm{fc}}$ is the stack current $(\mathrm{A}), \mathrm{T}_{0}$ is the ambient temperature $=27.5\left({ }^{\circ} \mathrm{C}\right), \mathrm{P}_{1}=-0.03802, \mathrm{P}_{2}=0.5095$, $\mathrm{P}_{3}=172.6, \mathrm{P}_{4}=1.1, \mathrm{P}_{5}=27.56$, are the empirical parameters obtained from curve fitting technique for this particular power module at different stack currents $(8.5,17.6$, and 25.5 (A)). The fitted curves for each current are shown in fig.5. According to equation (2), (3) and (4) a temperature dynamic block which represent the variation of stack temperature has been built. The inputs of this dynamic block are ambient temperature $\mathrm{T}_{0}$, and the stack current $\mathrm{I}_{\mathrm{fc}}$ and the output is stack temperature as a function of time.

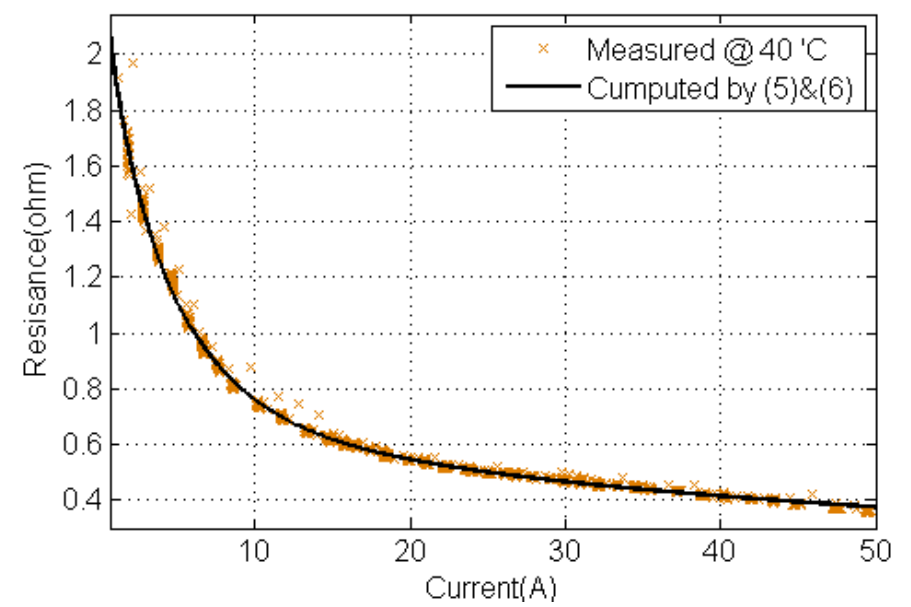

Fig.6. Comparison between the measured and computed equivalent internal resistance Rint.

\subsection{Dynamic of internal resistance}


The load characteristics of the module are investigated under different stack temperatures. Based on the experimental results as shown in fig.3, the equivalent internal resistance of the power module can best be described by:

$$
R_{\mathrm{int}}=f_{a}(T)+f_{b}(T) \times \exp \left(-f_{c}(T) \times I_{f c}\right)-f_{d}(T) \times \log \left(I_{f c}\right)
$$

whereRint is the equivalent internal resistance, $\mathrm{T}$ is the stack temperature and Ifc is the stack current and $\mathrm{f}^{*}(\mathrm{~T})$ is an empirical function which is represented by:

$$
f_{*}(T)=p_{1 *} T^{2}+p_{2 *} T+p_{3 *}
$$

To achieve reasonably accurate representation, the values presented in table. 2 have been selected from curve fitting technique. The synthesized curves and the measured data are shown in fig.6. These curves indicate a good match between the computed values based on the proposed models and experimental data. According to (5), (6), a dynamic resistance block of the Nexa ${ }^{\mathrm{TM}}$ power module has been developed and integrated into the proposed dynamic model. This dynamic block receives the stack temperature and the stack current and calculates the internal resistance of the module.

\subsection{Dynamic of no load voltage}

Table.2. The Empirical coefficients for the proposed equation

\begin{tabular}{ccccc}
\hline & $\mathrm{A}$ & $\mathrm{B}$ & $\mathrm{C}$ & $\mathrm{D}$ \\
\hline $\mathrm{P}_{1}$ & -0.00036 & 0.001358 & $2.65 \mathrm{E}-5$ & 0.000128 \\
\hline $\mathrm{P}_{2}$ & 0.02358 & -0.1579 & -0.006845 & -.01002 \\
\hline $\mathrm{P}_{3}$ & 0.6978 & 5.23 & 0.4699 & 0.0213 \\
\hline
\end{tabular}

As described in the section 3.3, when the stack temperature alters, the no load voltage varies. Using a curve fitting technique to the fig.7, dynamic characteristics of the no load voltage can be approximated by:

$$
V_{R}=V_{0}+\left(V_{f}-V_{0}\right)(1-\exp (b \times t))
$$

where $\mathrm{V} 0$ is the no load voltage of the stack when the stack temperature is equal to the ambient temperature. Here the V0 variable is set to 41.53 (V) which refers to the poor humidity level and Vf is the final no load voltage which derives at the final temperature and is approximated by:

$$
V_{f}=42.66+.7156 \times\left(1-\exp \left(\left(-.1714 \times\left(T_{f}-35.57\right)\right)\right)\right)
$$

here the final temperature $\mathrm{Tf}$ is current dependent and is expressed by (4) and the constant $\mathrm{b}$ has been calculated by:

$$
\left.b=-0.00925+0.003671 \times\left(1-\exp \left(\left(0.1314 \times\left(T_{f}-35.57\right)\right)\right)\right)\right)
$$

The results as shown in fig. 8 indicate a good match between the computed curve and experimental result. 


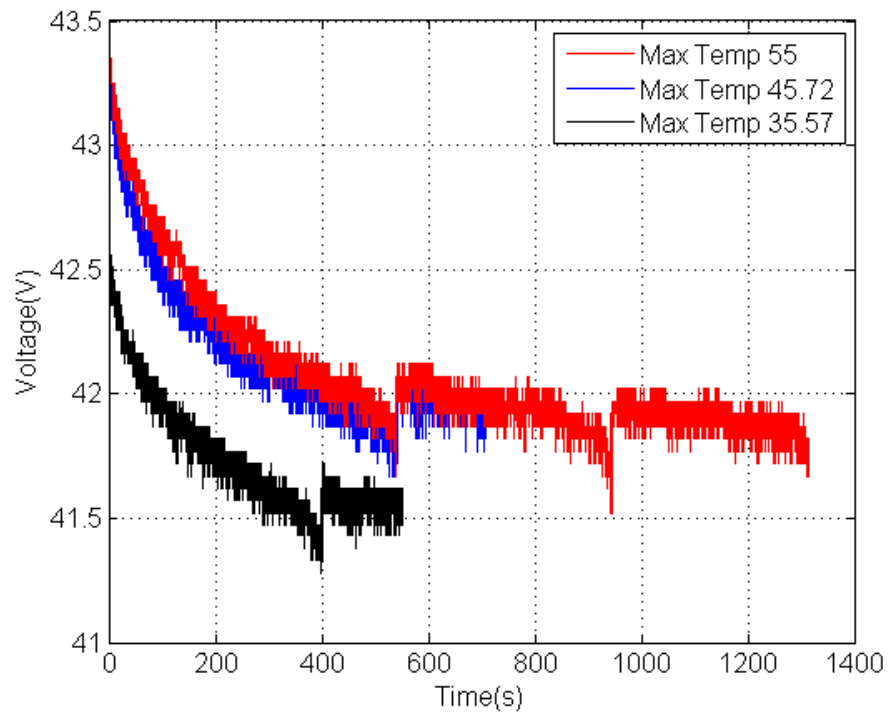

Fig.7. Variation of no load voltage when the final temperature decreases to the ambient temperature.

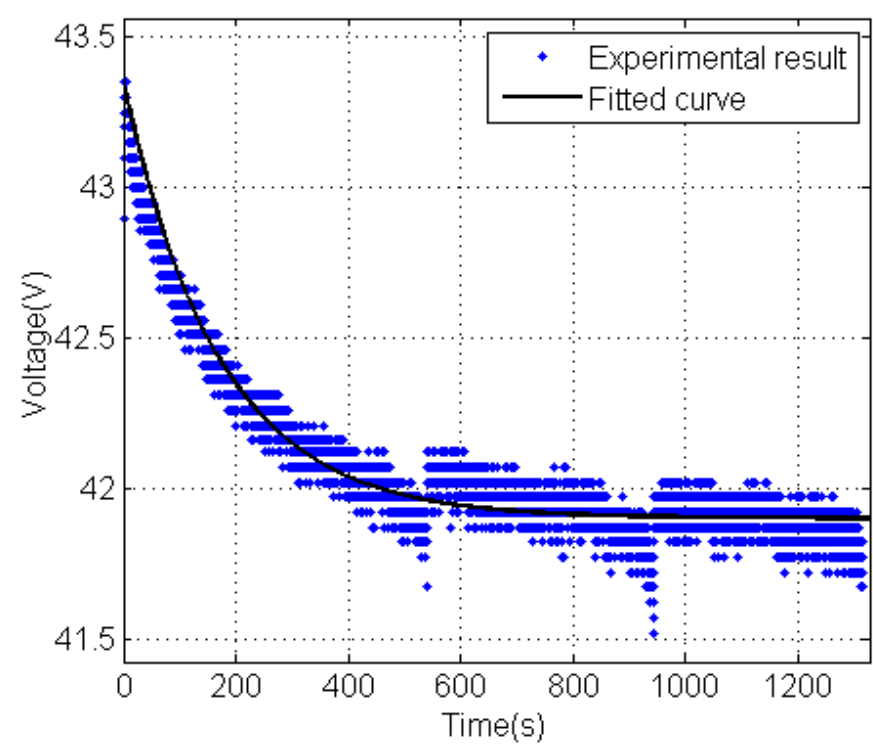

\section{Dynamic model of the stack}

Fig.8. Comparison between the measured and computed no load voltage

\subsection{Calculation of the stack voltage}

As described in section 3.2 the output voltage of fuel cell is always less than the open circuit voltage, because there are some voltage drops across the fuel cell. In order to calculate the output voltage, it is necessary to subtract the resistive losses from the no load potential and the internal consumption effect of the stack should be considered. However, as clarified in section 3.2 and described by (1), the internal resistance of the fuel cell system comprises the internal consumption as well as the no load voltage variations. As a result, the subtraction of internal resistance which multiplied to the stack current from the supposed no load voltage $(43.25 \mathrm{~V})$ is enough to calculate the output voltage. Due to the fact that the internal resistance as described by equation (1) includes the load current, in case of no load it cannot be useful for output voltage estimation. In such a situation the output voltage is equal to the no load voltage and is calculated directly from (7), (8) and (9). The above described method has been used to estimate the output voltage of the Nexa power module in this article. 


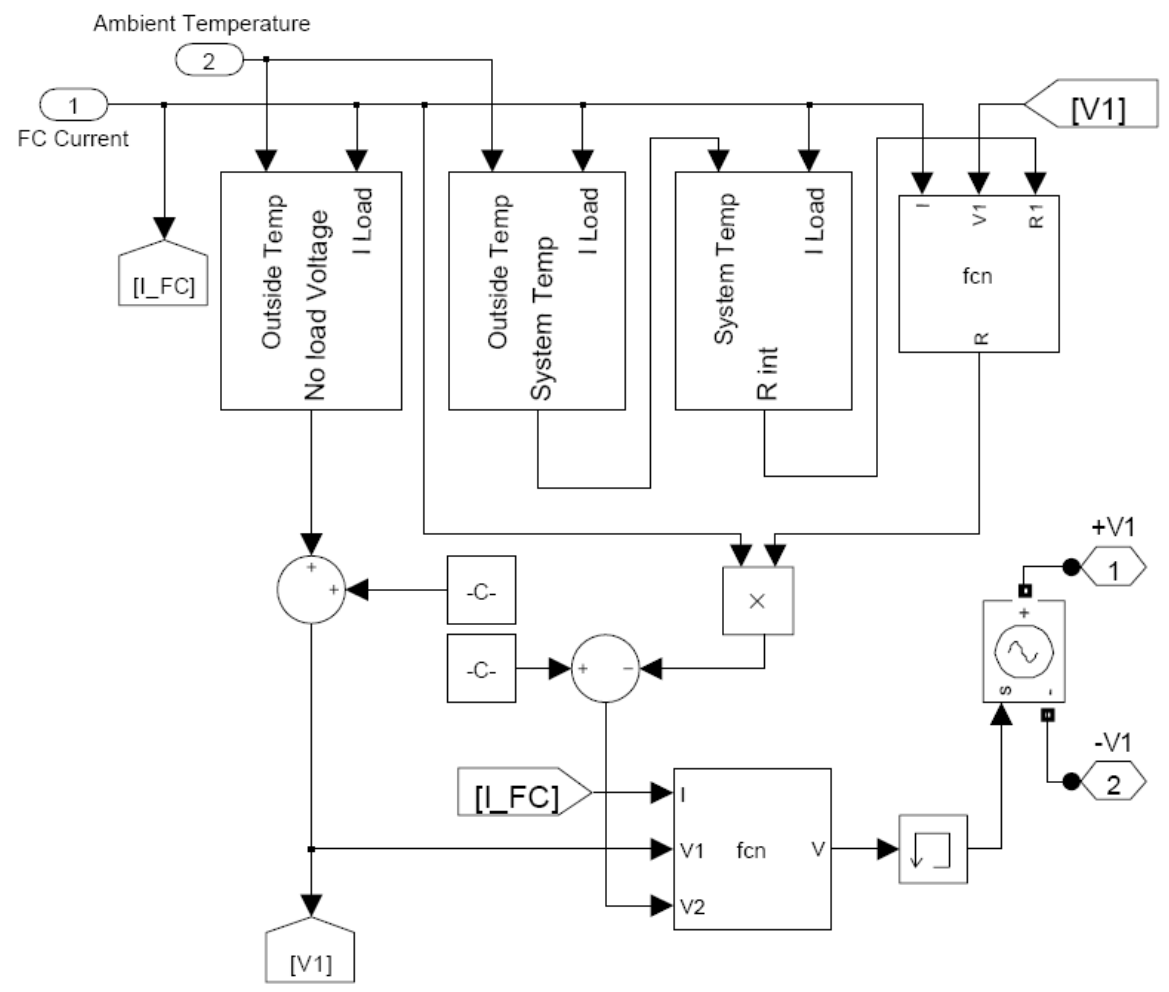

\section{Model validation and discussion}

The model described before, has been implemented using MATLAB ${ }^{\circledR}$ and Simulink ${ }^{\circledR}$ software packages by considering the effects of temperature, internal resistance and no load voltage as shown in fig.9. MATLAB ${ }^{\circledR}$ is a high-level technical computing language and interactive environment for algorithm development, data visualization, data analysis, and numeric computation [17]. The simulated results have been obtained based on the proposed model of the system in static as well as dynamic tests.

\subsection{Static and dynamic output characteristics}

To validate the static and dynamic characteristics of the output voltage with respect to load changes, some experiments as shown in fig. 10 to 17 have been carried out.

In order to validate the static characteristics of the voltage, three different experiments have been evaluated. In these experiments while the temperature was kept to a constant value, the variation of voltage versus variation of current has been recorded and the results are shown in fig.10. The static characteristics of voltage when the stack temperature is not constant (do not fix by controller) have been shown in fig.11. The results show a good match between the simulated result and experimental results in both constant temperature and variable temperature. When the fuel cells power plant provides power to a residential load or to the hybrid electric vehicles, the load may change dramatically. In order to verify the dynamic characteristics of the model, some step load as shown in fig. 12 was applied to the model and power module. 


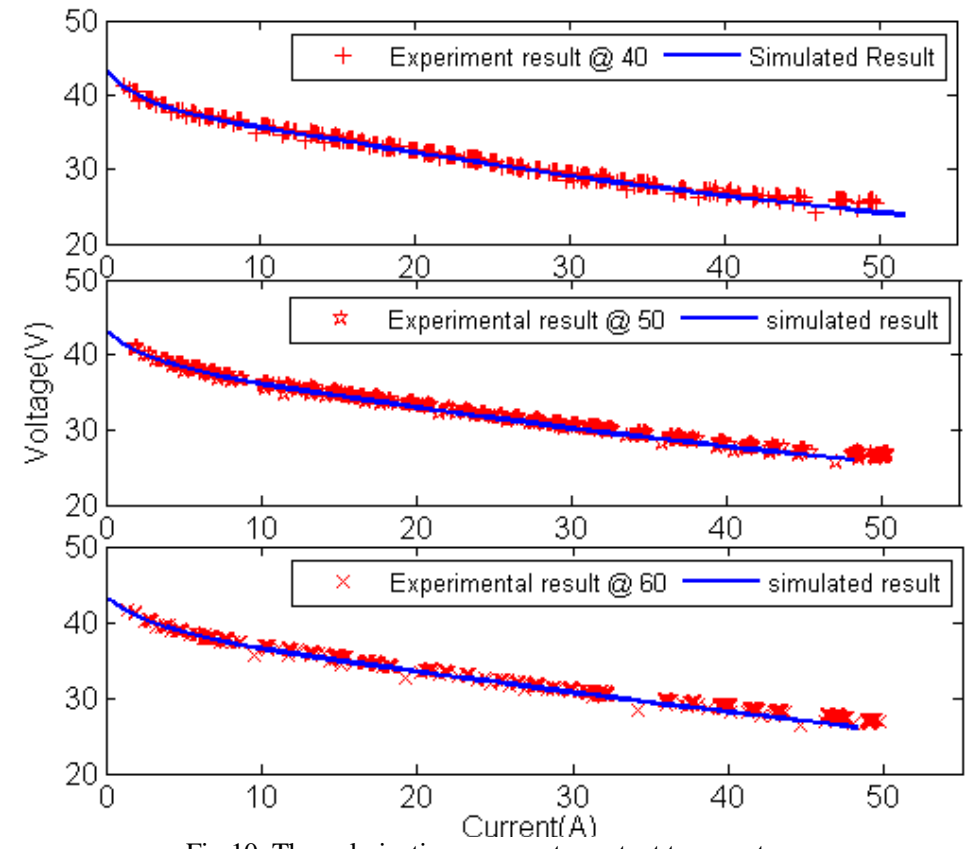

Fig.10. The polarization curves at constant temperatures

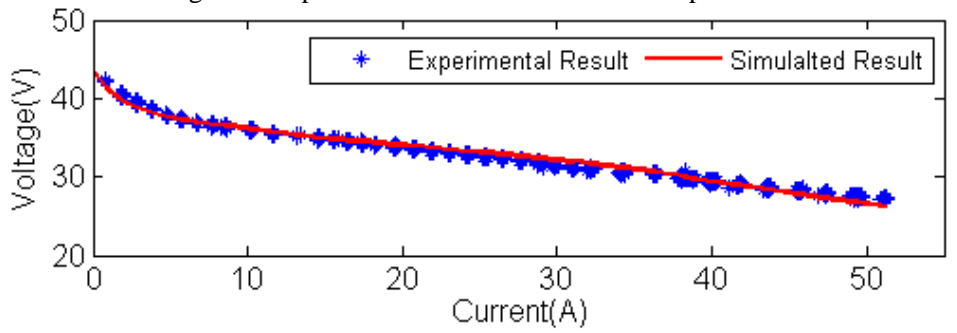

Fig.11. The polarization curve at variable temperature

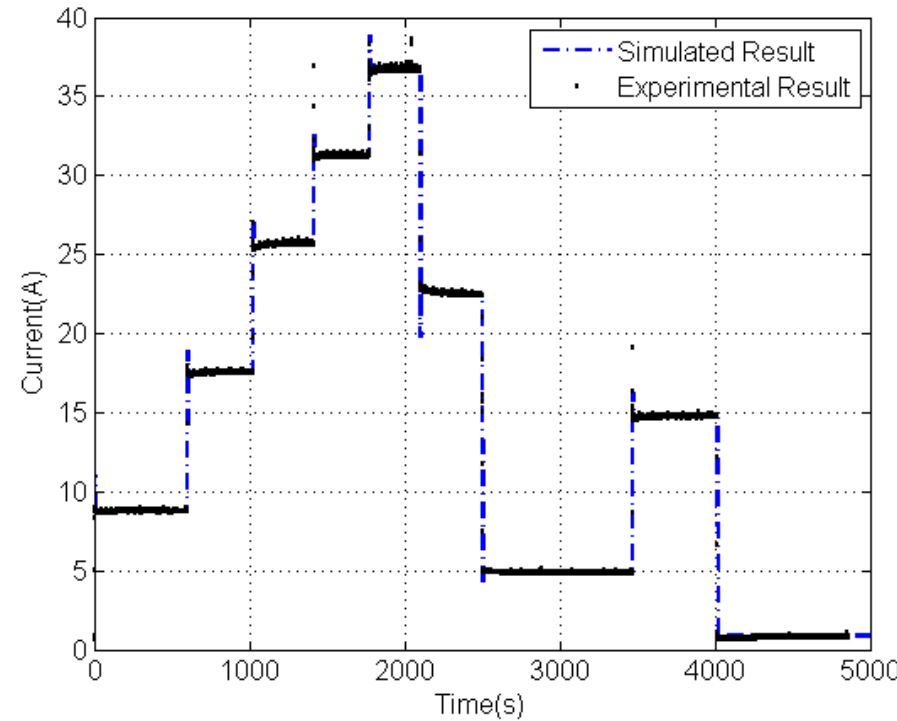

Fig.12. The step load applied to the model and system

The variations of voltage, temperature and internal resistance have been predicted in fig.13 to 15 . The curves obtained in experiments are also included in these figures. Obviously, a good agreement between the predicted response from the developed model and the measured data has been established. 


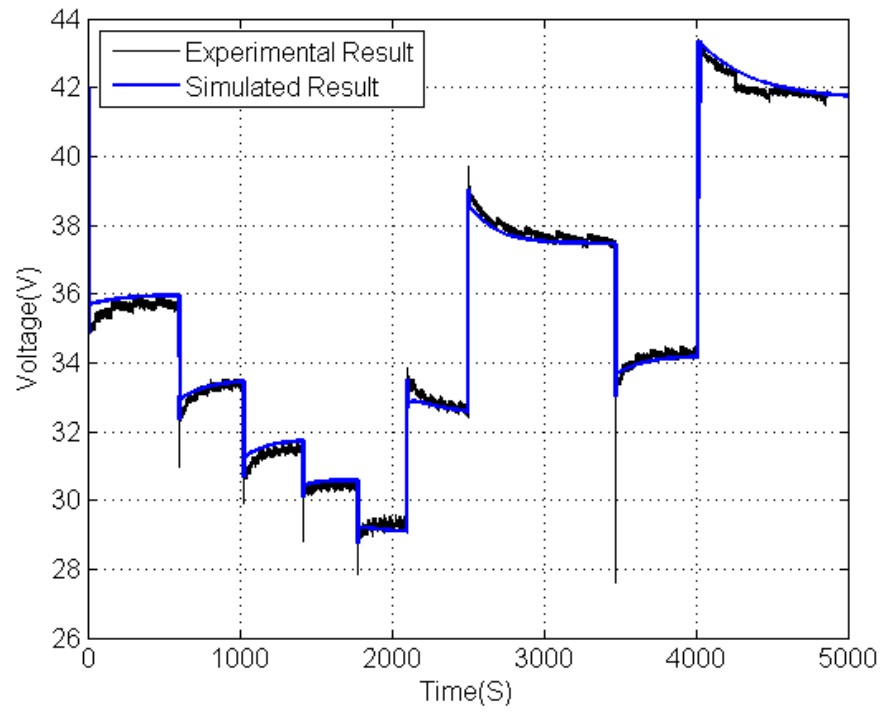

Fig.13. Comparison between the measured and simulated output voltage by the proposed model.

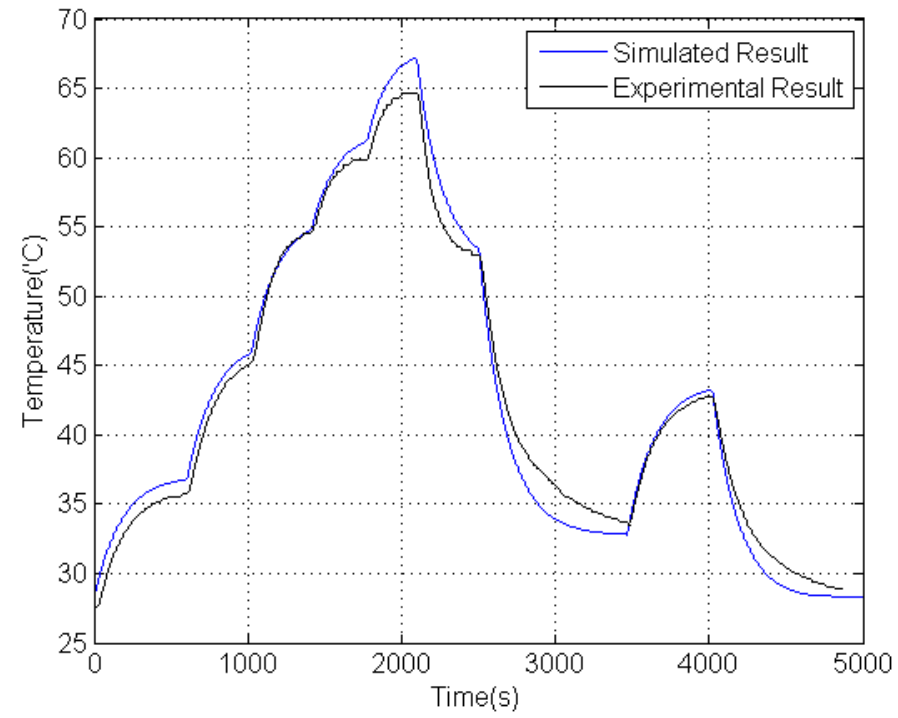

Fig.14. Comparison between the measured andsimulated stack temperatures by the proposed model.

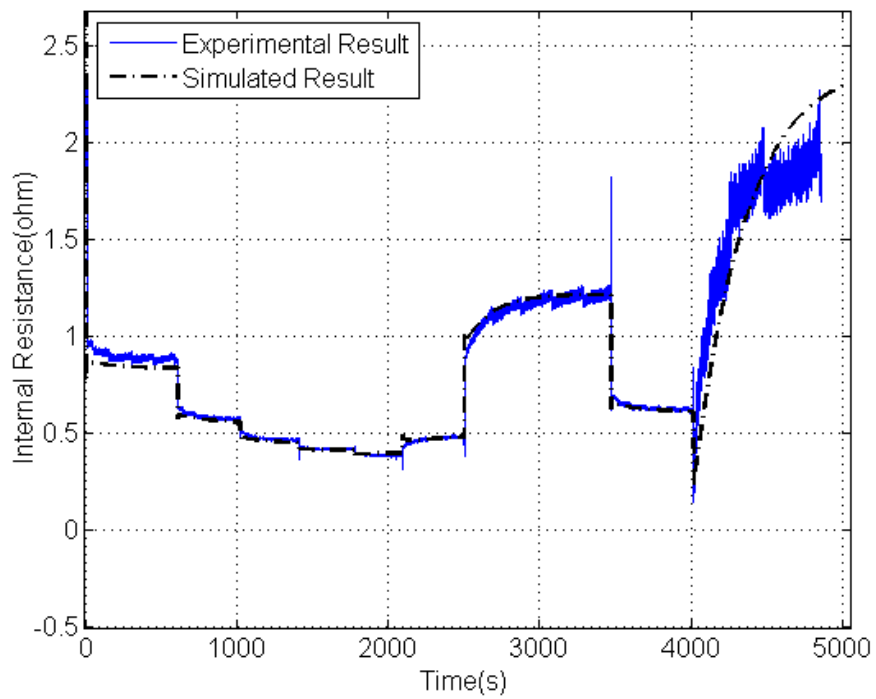

Fig.15.Comparison between the measured andsimulated equivalent internal resistance. 
As shown in fig. 12 at the beginning $t=0$ and the end of the experiment $t=4000$ the fuel cell works in no load condition. In such a situation the output voltage is equal to the no load voltage.

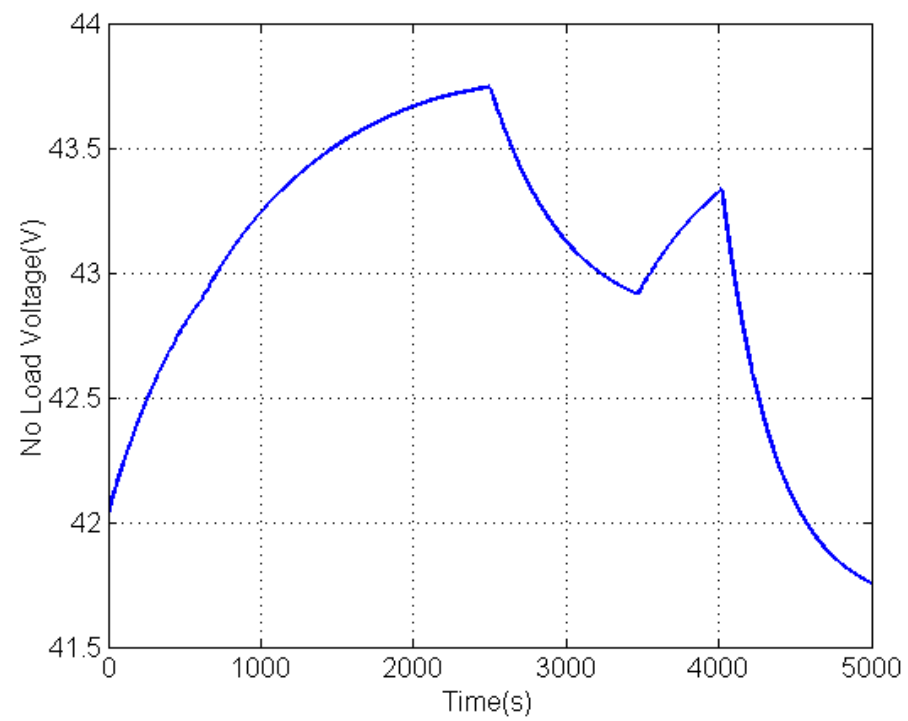

Fig.16. The variation of no load voltage when the stack temperature varies.

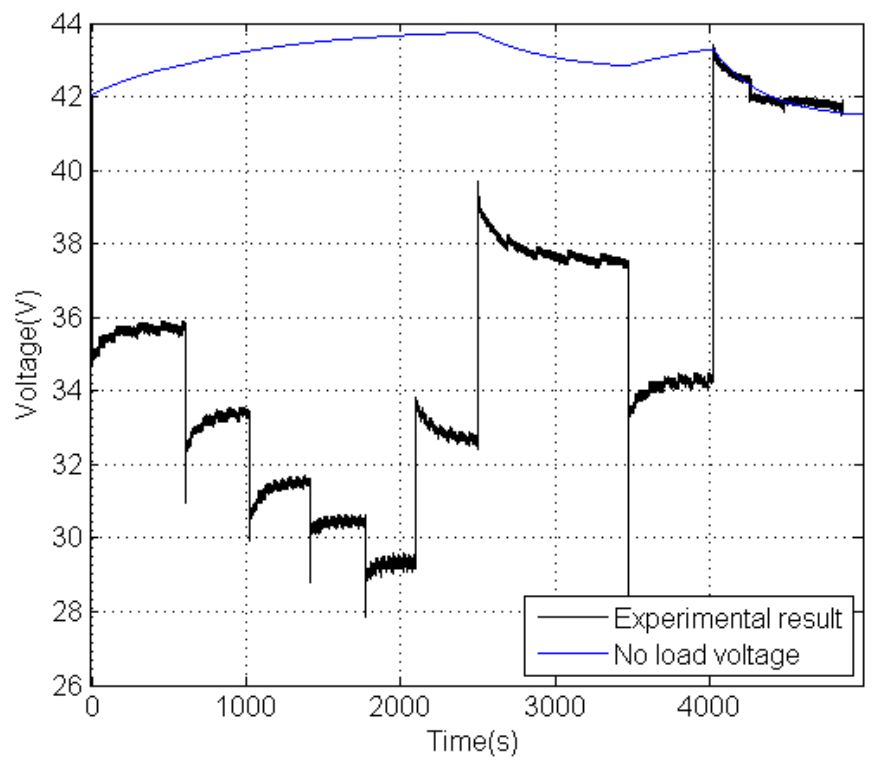

Fig.17. Comparison between the measured and simulated no load voltage by the proposed model.

Fig.16 clarifies the variation of no load voltage when the stack temperature varies. It is shown with fig. 17 that there is a good agreement between the no load voltage and experimental result when the fuel cell works in no load condition. In case of no load the internal resistance is calculated by (1) where VL is equal to no load voltage and Ifc is the internal consumption of fuel cell. From figures 12 to 13 it is evident that increase in the load current decreases the output voltage because of the increase in voltage losses on the internal resistance.

\section{Design and dynamic modeling of ultra-capacitor bank}

In this section, the equivalent circuit model of the UC bank used in the simulation has been proposed. Fig. 18 shows the classical equivalent circuit of the UC unit. The model consists of a capacitance (C), an equivalent series resistance (ESR) representing the charging and discharging resistance, and an equivalent parallel resistance (EPR) representing the self-discharging losses [18]. 
The EPR models leakage effects, affects long-term energy storage performance of the UC.The voltage state of a UC (i.e., RC circuit) with a capacitance $\mathrm{C}$ draining charge into a resistance $\mathrm{R}$ may be described as [20]

$$
V(t)=V_{i} \times \exp \left(-\frac{t}{R C}\right)
$$

The RC time constant determines the effective period of the charging and discharging processes for some initial voltage on the capacitor. The amount of energy drawn from the UC bank is directly proportional to the capacitance and the variation of terminal voltage [20], expressed as

$$
E_{U C}=\frac{1}{2} C\left(V_{i}^{2}-V_{f}^{2}\right)
$$

The effective specific energy for a prescribed load can be supplied by various UC bank configurations. In practical applications, the required amount of terminal voltage and energy or the capacitance of UC storage system can be built using multiple UCs in series and parallel.

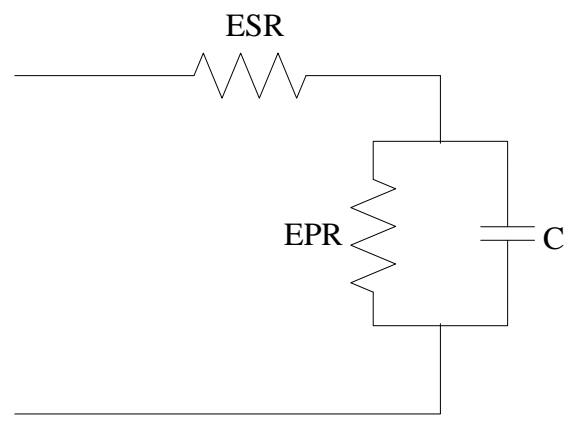

Fig.18. Classical equivalent model of the UC unit
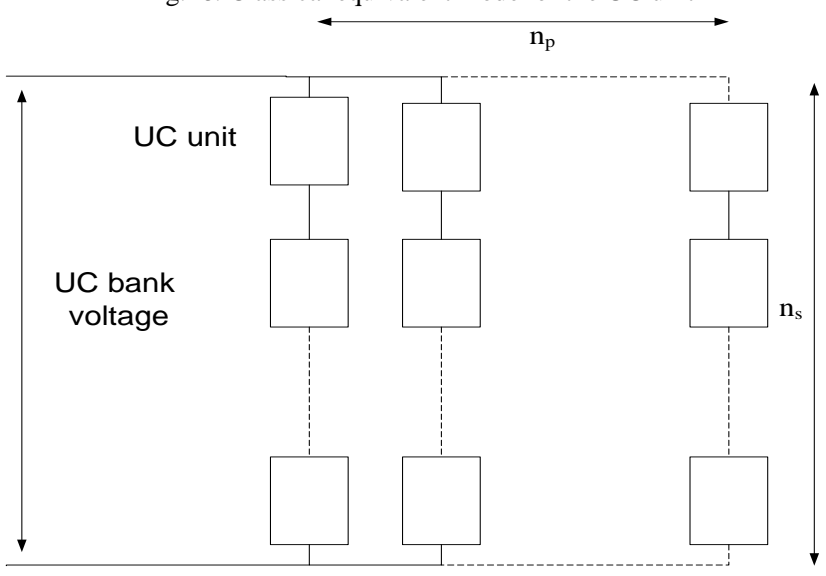

Fig.19. Arrangement of capacitors in a UC bank 


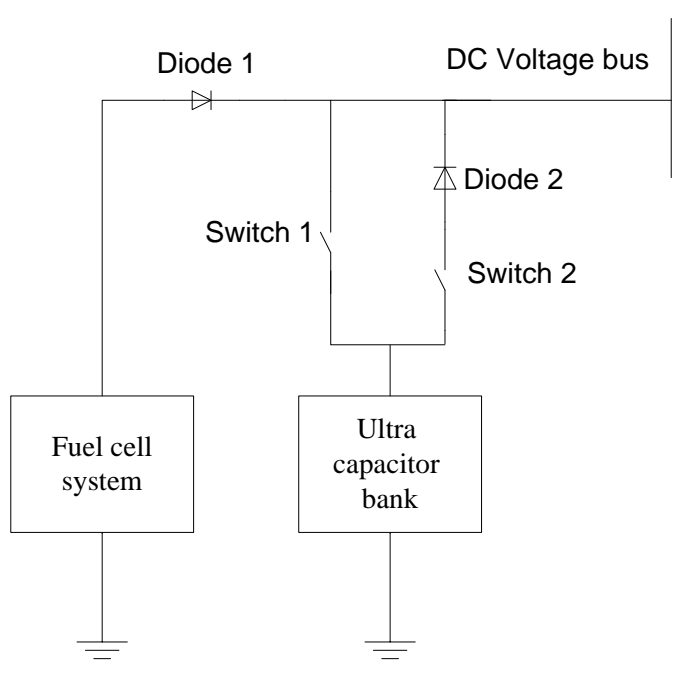

Fig.20. Fuel cell/Ultra-capacitor hybrid system

The terminal voltage determines the number of capacitors which must be connected in series to form a bank and the total capacitance determines the number of capacitors which must be connected in parallel.[20]. Fig. 19 shows, how a number of UC units can be arranged to build a UC bank that is capable of providing the peak load demand. The total UC system resistance and the total UC system capacitance of the UC bank are calculated as

$$
R_{U C-\text { total }}=n_{s} \frac{E S R}{n_{p}}, C_{U C-\text { total }}=n_{p} \frac{C}{n_{S}}
$$

\section{Combined FC And uc control system}

In this section, the integration of a FC system in parallel with a UC bank is presented. Various topologies may be used for integrating the UC with the FC power system [19]. For example, the UC system integration can be done with or without a power electronic converter via series and parallel connection. Because of the high specific power and power density of UC bank, it may be possible to eliminate the $\mathrm{dc} / \mathrm{dc}$ converter for voltage regulation so that it can deliver higher output [19]. Also, the direct integration of the FC with the UC bank is possible for relatively low-voltage applications with a $\mathrm{dc}$ bus of less than $50 \mathrm{~V}$ [20]. In this paper, we integrate a UC bank with the FC power module using a power diode, as shown in Fig. 20. This diode prevents the flow of reverse current from the UC bank into the FC system. This FC vehicle system topology, proposed by Honda [19], and is used in the current paper. The hybrid power source corresponds to the direct integration of the FC and UC in parallel, as illustrated in Fig. 20.

The direct integration of the UC bank with the FC system is attractive, because it does not require a high power $\mathrm{dc} / \mathrm{dc}$ converter and as a result, the complexity, cost, weight, and volume of the system are significantly reduced. Since losses in the diode is less important than that in a dc/dc converter, the efficiency of the overall system increases. The UC bank and the load terminal voltages depend on the FC system terminal voltage, which prevents the power capability of the UC bank from being fully utilized. Therefore, the UC bank size is restricted by the terminal voltage of the FC system. The power sharing between the FC system and UC bank is determined by the total resistance between these two systems. The main control strategy for the combined system which reported in [20], is shown in Fig. 20 and can be summarized as follows. 
1) During low power demand periods $(<1.2 \mathrm{~kW})$, the FC system generates up to its load limit, and the excess power is used to charge the UC. The charging or discharging of the UC bank occurs according to the terminal voltage of the overall load requirements.

2) During high power demand periods $(\geq 1.2 \mathrm{~kW})$, the FC system generates the rated power and the UC is discharged to meet the extra power that cannot be supplied by the FC system.

3) Short-time power interruptions in the FC system can only be supplied by the UC bank.

4) The UC bank is designed to avoid overcharge or undercharge conditions.

5) About $75 \%$ of the initial energy stored in the UC bank can be utilized if the terminal load voltage is allowed to decrease to $50 \%$ of its initial value.

To realize the control system of the above mentioned combined system, PI controllers, ideal switching elements, and current and voltage sensors are used in the simulation model.

\section{Simulation results}

The proposed PEMFC system operates with a UC bank connected in parallel with the dc bus via a diode. The voltage drop in the diode is assumed to be $0.7 \mathrm{~V}$. The UC bank serves as a short duration power source to meet load demand that cannot be met by the FC system, particularly during transient or peak demand periods. In this study, the UC bank is used to provide the difference between the load and the FC system output power. Simulation results are obtained by developing a detailed MATLAB®, Simulink®, and SimPowerSystems-based software packages using the mathematical and electrical models of the systems as described earlier. The load profile is randomly selected for this study. From this load profile, it is evident that the average power demand is less than $1.2 \mathrm{~kW}$. However, the load profile during peak load periods varies from 46 to $50 \mathrm{~A}$, as illustrated in Fig. 21. The proposed UC system is capable of sustaining the extra load of $0.6 \mathrm{~kW}$ for $75 \mathrm{~s}$ (i.e. $12.5 \mathrm{~W} \cdot \mathrm{h}$ of energy) during peak demand periods. Thus, the energy capacity of the UC bank must have a minimum rating of $12.5 \mathrm{~W} \cdot \mathrm{h}$. In this work the Maxwell BMOD0165-E048 V UC bank has been selected, whose characteristics are shown in Table 3.

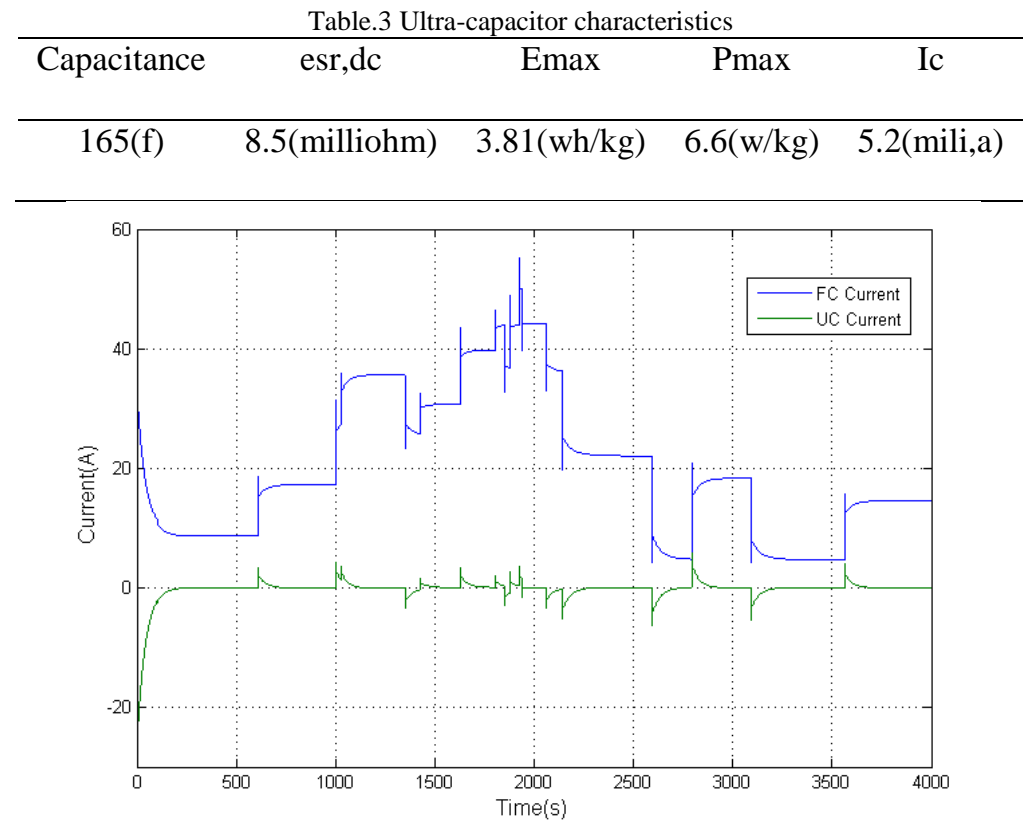

Fig.21 FC current and UC current obtained by the proposed model. 


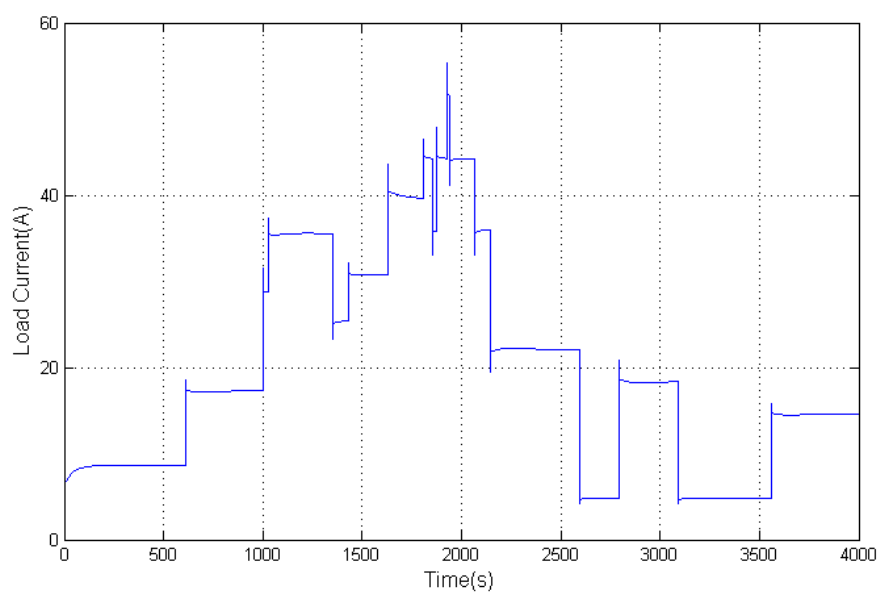

Fig.22 Load Current applied to the hybrid system

This UC bank has a nominal voltage of $48 \mathrm{~V}$ and 165 Farad capacitance. Knowing that the maximum voltage of $\mathrm{FC}$ is $43 \mathrm{~V}$, the energy stored in the $\mathrm{UC}$ at $43 \mathrm{~V}$ is equal to $42.37 \mathrm{~W} \cdot \mathrm{h}$. The required energy for the above mentioned vehicular load is $600 \times(75 / 3600)=12.5 \mathrm{~W} \cdot \mathrm{h}$. However , at full load conditions the FC output voltage falls down to $26 \mathrm{~V}$, so the stored energy will be $15.49 \mathrm{~W} \cdot \mathrm{h}$. Therefore, in direct integration of UC bank with the FC system, the lowest voltage of the FC should be considered to design the UC bank.

The output power of the FC system is limited to $1.2 \mathrm{~kW}$. Figs. 21-22 show the simulation results of the FC/UC hybrid system, including FC system output current, UC bank current, and Load Current, respectively versus time. In Fig. 21, it is evidence that the FC system supplies the load current up to its current limit (46 A). During peak load demand, the UC bank supplies the extra required power.

\section{Conclusion}

Firstly an exact FC model which is capable of characterizing fuel cell's steady state performance as well as dynamic behavior has been proposed based on the methods of parameter estimation. Finally a UC-based storage system has been designed for a PEMF Cooperated Hybrid vehicle to supply the extra power required during peak demand periods. The parallel combination of the FC system and UC bank exhibits good performance for vehicular applications during the steady-state, load-switching, and peak power demand. Without the UC bank, the FC system must supply this extra power, thereby increasing the size and cost of the FC system. The lifetime of a FC system can be increased if combined FC system and UC bank is used instead of a stand-alone FC system or a hybrid FC and standby battery system.

\section{Acknowledgment}

The author would like to thank Tiran Branch, Islamic Azad University for the financial support of this research, which is based on a research project contract.

\section{Reference}

[1]Woojin Choi ,Jo.W. Howze, Prasad Enjeti, "Development of an equivalent circuit model of a fuel cell to evaluate the effects of inverter ripple current", Journal of Power Sources, vol. 158, pp. 1324-1332, 2006

[2]J. Larminie, A. Dicks, "Fuel Cell Systems Explained", second ed., John Wiley\& Sons, 2003 (chapter 1).

[3]M. Uzunoglu, M.S. Alam, "Dynamic modeling, design and simulation of a PEM fuel cell/ultra-capacitor hybrid system for vehicular applications", Energy Conversion and Management, vol. 48, pp. 1544-1553, 2007

[4]Christos N. Maxoulis, Dimitrios N. Tsinoglou, Grigorios C. Koltsakis, "Modeling of automotive fuel cell operation in driving cycles", Energy Conversion and Management, vol. 45, pp.559-573, 2004. 
[5]Bernardi DM, Verbrugge MW, "A mathematical model of the solid- polymer-electrolyte fuel cell", Journal of Electrochemical Society, vol. 139(9), pp.2477-2491, 1992.

[6]Springer TE, Zawodzinski TA, Gottesfeld S. "Polymer electrolyte fuel cell model". Journal of Electrochemical Society, vol.138(8), pp.2334-2342, 1991.

[7]Berning T, Lu DM, Djilali N. "Three-dimensional computational analysis of transport phenomena in a PEM fuel cell", Journal of Power Sources, vol.106, pp. 284-294,2002.

[8] J C Amphlett, R M Bumert, R F Mann, B A Peppley, and P R Roberge, "Performance modeling of the ballard mark IV solid polymer electrolyte fuel cell II: Empirical model development", Journal of the Electrochemical Society, vol. 142, pp. 9-15, 1995.

[9]Fowler MW, Mann RF, Amphlett JC, Peppley BA, Roberge PR. "Incorporation of voltage degradation into a generalized steady state electrochemical model for a PEM fuel cell". Journal of Power Sources, vol.106, pp.274-83, 2002.

[10]J. Padulle's, G.W. Ault, J.R. McDonald,"An integrated SOFC plant dynamic model for power systems simulation", Journal of Power Sources, vol. 86, pp.495-500, 2000.

[11]M.Y. El-Sharkh, A. Rahman, M.S. Alam, P.C. Byrne, A.A. Sakla, T. Thomas, "A dynamic model for a stand-alone PEM fuel cell power plant for residential applications", Journal of Power Sources, vol.138, pp.199-204, 2004.

[12]M. Uzunoglu, O.C. Onar, M.S. Alam, "Dynamic behavior of PEM FCPPs under various load conditions andvoltage stability analysis for stand-alone residential applications", Journal of Power Sources, vol.168, pp.240-250. 2007.

[13]W.H. Zhu, R.U. Payne, D.R. Cahela, B.J. Tatarchuk, "Uniformity analysis at MEA and stack levels for a Nexa PEM fuel cell system", Journal of Power Sources, vol.128 pp.231-238, 2004.

[14]Nexa ${ }^{\mathbf{T M}}$ (310-0027) Power Module User's Manual, Ballard Power Systems Inc., 2003.

[15]Alejandro J. del Real, Alicia Arce, Carlos Bordons,"Development and experimental validation of a PEM fuel cell dynamic model", Journal of Power Sources, vol.173, Issue.1, pp.310-324, 2007.

[16]http://www.mathworks.com/products/curvefitting, 2008.

[17]http://www.mathworks.com/products/matlab/description1.html, 2010.

[18]R. L. Spyker and R. M. Nelms, "Analysis of double-layer capacitors supplying constant power loads"IEEE Trans. Aerosp.Electron. Syst., vol. 36, no. 4, pp. 1439-1443, Oct. 2000.

[19]Honda Fuel Cell Power FCX (Dec. 2004). [Online]. Available: http: //world .honda.com/ FuelCell/ FCX/ FCXPK. pdf, Press Information, 2004.12

[20]M. Uzunoglu, M. S. Alam, "Dynamic Modeling, Design, and Simulation of a Combined PEM Fuel Cell and Ultracapacitor Systemfor Stand-Alone Residential Applications" IEEE Trans. Energy Conversion, VOL. 21, NO. 3, pp. 767-775 Sep. 2006

\section{Biography}

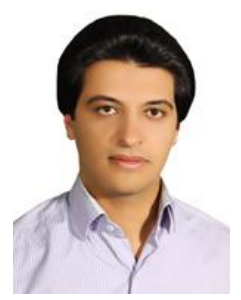

Mehdi Soltani, He was born in Iran in 1981. He graduated from the K. N. Toosi University of technology in Tehran/Iran in 2007. His current research interest includes fuel cells, distributed generations, and Hybrid Electric Vehicle. 